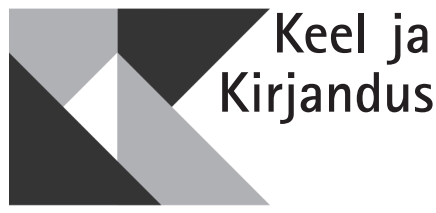

\title{
JAAK PÕLDMÄE VÕRDLEVALT VAATEKOHALT
}

\author{
PEETER OLESK
}

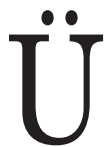

hel varakevadisel päeval aastal 1976 pidi Jaak Põldmäe (1942-1979) viima kirjastusse Eesti Raamat oma raamatu „Eesti värsiõpetus” (1978) käsikirja. Eellepingu põhjal oli talle makstud välja $60 \%$, kuid kirjastus küsis, kuhu jääb käsikiri. Sõidueelseks õhtuks kutsus Jaak Põldmäe Sirje Mägari ja Peeter Oleski Tähtverre appi käsikirja kokku panema. Vastu hommikut väsis tulevane Sirje Olesk ära. Jäime Jaak Põldmäega kahekesi. Seadsime paberid korda ja tema sõitis Riiast tulnud rongiga Tallinna. Mina läksin teda asendama aines „Sissejuhatus kirjandusteadusesse”, kus pidi toimuma värsiõpetuse praktikum. Mitte küsimuses „mis on värss?”, vaid heksameetri morfoloogias.

Jaak Põldmäe ei pidanud loenguid, nagu esinesid Cicero ja Cato Vanem Roomas. Väliseid efekte ei olnud, adamslik teatraalsus puudus. Ta võlus oma pühendumusega. Ta ei lugenud oma ainet selle järgi, et see on nii seatud ja tuleb, maksku, mis maksab, läbi võtta. Tema õpetas seepärast, et oli veendunud: seda on vaja. Samamoodi arvasid mitmed teisedki, näiteks meie foneetika õppejõud Arvo Eek (1937-2009). Ja selle tundis akadeemiline rebane ära väga kiiresti. Osalt kirjutan ma järgnevas seega armastatud õpetajast, osalt oma väga lähedasest sõbrast.

Mida tähendab seejuures võrdlev vaatekoht? Meiesugustel polnud võrrelda Jaak Põldmäed kellegagi, sest keskkoolis ei õppinud me poeetikat Bernard Söödi (1900-1976) „Kirjandusteooria lühikursuse” (1959; 1966) järgi ja värsiõpetust ei saanud me üldse. Ei olnud nii, et igas kodus leidunuksid „Kalevipoja" tekstikriitiline väljaanne 1961-1963 ning Homerose eeposte tõlked ja kõik kooliõpetajad osanuksid selgitada, mis on kvantiteet silbis ning kuidas 
seda mõista sõna rõhkudega seotult. Olnuks isegi hea, kui me mõistnuksime, et värss võib olla koguni ühesilbiline, nagu Mart Raua luuletuses „Mis Krõlov lõvi surmast arvas?" (1971), ent see ei ole pikem kui trükirida. Kuid Jaak Põldmäe nägi, et me oleme juba ülikoolis, teadmata suurt midagi sellest, mis on filoloogia kui teadus.

Võrdlev vaatekoht seisneb siinkohal selles, et on võimalik kõrvutada Jaak Põldmäe käsitlust värsist matemaatiku Andrei Kolmogorovi (1903-1987) ning kirjandus- ja värsiteadlase Mihhail Gasparovi (1935-2005) käsitlustega. Võrdlus lähtub kummagi nendest töödest, mis ilmusid Jaak Põldmäe stuudiumija alustava õppejõu aastail. Hilisemate uurimuste vaatlemine siinkohal oleks pisut meelevaldne. Samuti oleks spekulatiivne võrrelda Jaak Põldmäe ning Harald-Heino Peebu (1931-1998) kirjandusloolisi arusaamu, sest Jaak Põldmäe ei õpetanud eesti kirjanduse ajalugu. Nad leppisid küll kokku, et vahetavad kirjandusteooria ja XX sajandi eesti kirjanduse ajaloo kursused omavahel ringi, aga enne Jaak Põldmäe haigestus ning doktorantuuris - mille eesmärgiks oli monograafia eesti värsi ajaloost - oli ta õppetööst vabastatud. Põhimõtteliselt võiks võrrelda Jaak Põldmäe ja Viktor Grigorjevi (1925-2007) käsitlusi sõna poeetikast. Jaak Põldmäe tundis seda kinnisevõitu, kuid äärmiselt sümpaatset Moskva lingvisti isiklikult ja oli kursis tema esimeste suurte uurimuste ning uurimisprojektidega. Viktor Grigorjev töötas Vene Keele Instituudis, ent tal puudus instituudi kauaaegse direktori, akadeemik Viktor Vinogradovi (1894-1969) ühemõtteline toetus, kuna Vinogradov reserveeris ajaloolise poeetika enesele. Jaak Põldmäe seisukohalt oli Viktor Grigorjev dissident akadeemilises mõttes. Mida Viktor Grigorjev õieti taotles? Seda, et toimiks vastukaal normatiivsele kalduvusele esitada mis tahes sõna võimalikult tähenduskitsana, peaaegu nagu oskussõnana. Siis oleks tähendus küll defineeritud, aga mitte interpreteeritud. Normatiivses leksikograafias ongi sõna kodifitseerimine paratamatu. Luules viiks see aga bipolaarse häirituseni. Jaak Põldmäe arvas sedasama. Kust ma seda tean? Ei mujalt kui vestlustest temaga Viktor Grigorjevi raamatu „Luuletaja ja sõna. Katsesõnastik” („Поэт и слово. Опыт словаря", 1973) teemal.

Andrei Kolmogorov polnud matemaatikas küll entsüklopedist, kes käsitleks „kõike arvudest kuni $n$-mõõtmelise ruumi kujutava geomeetriani”, ent ta oli universaal rõhuasetustega eeskätt funktsionaalanalüüsil, tõenäosusel, statistikal, loogikal ja matemaatika õpetamisel poolel teel elavate arvude ning kõrgema matemaatika elementide vahel. „Poolel teel” tähendab siinkohal kaht erinevat asja. Üks on koolimatemaatikas üleminek numbriliselt baasilt hulgalisele baasile ehk araablaste juurest saksa matemaatiku Georg Cantori (1845-1918) manu. Jaak Põldmäe matemaatiline põhiharidus oli araabialik, niisiis hilisema Kolmogorovi eelne. Ta ei saanud õppida matemaatikat Kolmogorovi järgi, sest kuigi Andrei Kolmogorov hakkas algebra ja matemaatilise analüüsi alustega üldhariduse tarbeks tegelema hiljemalt juba 1930. aastate lõpul, ilmus tema esimene sellesihiline õpik „Sissejuhatus matemaatilisse analüüsi” alles aastal 1966, mil Jaak Põldmäe oli 5. kursuse tudeng. Põldmäe (nagu minugi) kooliea õpetajad suhtusid hulgateooriasse tõrjuvalt, kuna see oli nende jaoks liiga abstraktne, niisiis ka väheempiiriline. Lapsevanemate jaoks oli hulgateooria jällegi midagi säärast, milles nad polnud võimelised kodus oma järglasi järele aitama. Andrei Kolmogorovi värsiõpetusse see otseselt ei puutu, ent see iseloomustab aega, mil Jaak Põldmäe küsimuseks sai, kuidas arvutada värsside mõotu kahel erineval juhul: siis, kui värssi tuleb tõlkida, 
ja siis, kui värss sünnib algupäraselt. Oli vaja statistiliseks analüüsiks relevantseid parameetreid ning nende kirjeldamiseks matemaatiliselt korrektseid lahenduskäike. Mõlema esitamine oligi Andrei Kolmogorovi elutöö üks osa, ehkki ta ei olnud ettevalmistuselt värsiteadlane. Ta ise pidas end puhtaks matemaatikuks, kellel tuleb alalõpmata lahendada puhtpraktilisi ülesandeid, näiteks kristallisatsiooni kiirus metallides (1937). Vene värsiõpetuse võttis Kolmogorov käsile aastal 1943, mil ta kirjutas sellekohase juhendi oma majakaaslase, akadeemik Pavel Aleksandrovi (1896-1982) ja iseenda kasvandikule, hilisemale professor Juri Smirnovile (1921-2007), kes kirjutas luuletusi värsiõpetust tundmata.

Väljendil „poolel teel” on ka teine tähendus. Selle väljaks on verifikatsioon ehk sündmuse kinnitamine võimalikult lõplikult. Verifikatiivsetest parameetritest näikse Andrei Kolmogorovit huvitanuvat kaks, nimelt adekvaatsus ja alternatiivsus. Kirjeldus peab olema küllaldane, kuid ühtlasi ka klassifitseeritud (st mitte-puhtsubjektiivne), mis iga kord aga ei tähenda, et see on ainuvõimalik (eriti kui tuua sisse tõenäosus). Saab öelda, et Kolmogorov otsis adekvaatsuse maksimumi - mis on matemaatilise analüüsi põhiprobleem -, ent ta pidi leppima alternatiivsusega näiteks küsimuses, kumb on piisavam, kas funktsiooni graafik joonena Descartes'i koordinaatteljestikus või analüütilisel kujul (jutt on piisavusest, mitte rangusest). Eemalseisjal on võimatu kirjeldada, kuivõrd oli verifikatsioon Kolmogorovi jaoks filosoofiline probleem, kuid ei maksa kahelda selles, et ta pidi alatasa otsustama selle üle, mis on matemaatikas puhtintuitiivne (nt arvu puudumine), mis definitiivne (nt tühi hulk), mis aksiomaatiline (nt Peano 1. aksioom) ja mis derivatiivne (nt trigonomeetriline funktsioon). Ta sekkus asjadesse siis, kui tekkis tunnetuslik kriis, mida lahendada püüdes oli ta ettevaatlik heurist. Heurist ei ole mitte lihtsalt leidja. Ta leiab teatava korra. Värsiõpetuses tähendab kord fonoloogilist korrelatsiooni ühe keele „sees” ja luule tõlkimisel keelte vahel. Matemaatiliselt üldisemas mõttes võib sedasama asjaolu sõnastada kolmeastmelise küsimusena: kuidas tekib kord ühes hulgas (mis ei ole tühi), kuidas tekib kord hulkade vahel ja kuidas on ehitatud üles ülekanne hulgast hulka? See, et üks hulk peegeldub teises, ei ole ammendav vastus.

Mihhail Gasparov oli sünnipäraselt armeenia juut, mittevenekeelselt Michael Gasparjan. Ta tundis klassikalisi keeli (salgamata, et oli kirjandusteadlane, mitte lingvist) ja oskas umbkaudu seitset keelt. Ta oli viljakas tõlkija, tõlgete kommenteerija, eeskätt kreeka muistse kultuuri lahtirääkija, värsiteadlane, ent filoloogina ka eetiliselt autoriteetne etalon. Moskva oludes tähendas see, et temas puudus kammerteenerlikkus. Ta ei olnud koolutatav, vaid säilitas sõltumatuse muuhulgas selleski, et ta ei läinud libedale. Kirjandusteaduses avaldub libedus näiteks vallas nimega „loominguline meetod”. Sellekohaseid artikleid Mihhail Gasparovil ei ole. Pragmaatiliselt ta siiski mõtles. Raamatu „Vene värsiasjandus XIX sajandil. Materjale vene luuletajate meetrikast ja stroofikast” („Усское стихосложение XIX в. Материалы по метрике и строфике русских поэтов”, 1979; Põldmäele saatis Gasparov selle kolm kuud enne Jaagu surma) on pannud kokku kolleegium, kuhu kuulus ka NSVL TA kirjavahetajaliige Leonid Timofejev (1904-1984). Pärast 1940. aastat tegeles Timofejev peamiselt „ideoloogilise poeetikaga” ja oli võrdlemisi sallimatu ning, välja arvatud pugejad, ka väheautoriteetne. Tema peamine panus Põldmäe tööaastail seisnes selles, et ta kutsus NSVL TA Maailmakirjanduse Instituudi juurde kokku värsiteaduse töörühma ja visandas aastatel 1968-1970 
programmi meetriliste teatmike koostamiseks. Värsiteaduses oli Gasparov empiirik, kes tegeles küsimusega, missugustel tingimustel mahub reaalne sõna ära värssi, ehk, teistpidi võttes, kuidas sunnib meetriline eeskiri, paljudel juhtudel ka meetriline inerts, sõnu valima (tihtigi mitte ootuspäraselt, vaid just vastupidi). Tõlkimisel ei olnud tema probleemiks Bühnenlatein (saksa Bühnendeutsch'i eeskujul: eriti lihvitud, eeskujulik ladina keel). Probleemiks oli kvantiteeriva värsi ekvivalent aktsenteeritud värsis ehk ekvimeetrilisus ehk konflikt erinevate värsisüsteemide vahel. Või ka - kuidas mõõta värssi siis, kui see ei ole mooraline ehk ei lähtu lühikese silbi pikkusest kui elementaarühikust. Selles mõttes ei olnud Gasparov aksiomaatik nagu Põldmäe. Ta uuris meetrilises struktuuris positsioonide täidetavust, mitte seda, kuidas niisuguseid positsioone kirjeldada keelest sõltumatult. Gasparovi järgi peab tekst olema tõlgitav ehk alluma tõlkimisele (reaalust ja proosatõlget ta pikemalt ei käsitle) ja kaotama tõlgituna võimalikult vähe. Jaak Põldmäe järgi dikteerib nii teksti kui ka tema tõlke keelte erinevus. Häälikute pikkus ei ole seesama mis silpide rõhulisus. Seda rõhutas juba Ain Kaalep.

Kahjuks ei ole meil kasutada ainsatki allikat, mis kinnitaks, kuidas pöördus Jaak Põldmäe värsiteaduse poole. Harald Peep ja Karl Muru uurisid luulet, mitte värssi. Esimene tegi seda sotsioloogiliselt, teine temaatiliselt vaatekohalt. Võib-olla osutus Jaak Põldmäele määravaks Ain Kaalep, kelle artikkel „Eesti keele fonoloogilise struktuuri ja eesti värsiõpetuse suhetest” (1959) on tegelikult väga põhimõtteline. Mis suhtes? Asjaomaseid punkte on vähemasti kolm: 1) eesti värsi võimalused tulenevad eesti keele iseärasustest, milles häälikute kvantiteet ei ole rõhu ees taandunud; 2) eesti luule värsiloomes on värsisüsteemide hulk suurem kui kolm; ning 3) kreeka- ja ladinakeelse luule tõlkimisel eesti keelde oleks loomuvastane trampida eesti keele kvantiteetilisus aktsenteerituse jalge alla. Kui need kolm punkti kehtivad, siis saaksime järgmise tõlkijate loendi: Karl Reitav (1897-1961), Ülo Torpats (1920-1988), Ain Kaalep, Valmen Hallap (1928-1987), viimane kreeka klassikute reaaluse tõlkijana Ellen Niidu heaks. Mitte ükski neist ei uurinud aga värssi statistilises mõttes ega ole usutav, et nad lugenuksid Andrei Belõi (1880-1934) raamatut „Sümbolism” („Символизм”, 1910) nõndasamuti kui Gustav Suits, Johannes Semper ja Valmar Adams. Nad ei lähtunud mitte sellest, milline peaks olema eesti omavärss, vaid sellest, kuidas peaks teiskeelne värss olema eesti keelde üle kantud. Ilmtingimata ei ole see matemaatiline probleem, ent see on probleem juhul, kui tuleb otsustada, millisel viisil saab näiteks algupärast puhtkvantiteerivat heksameetrit anda edasi eesti keeles, kus silbi pikkus ja sõna rõhk omavahel konkureerivad. Gustav Suitsu antiigitundmine ei ole väga arusaadav ja on küsitav, kuivõrd sünkroonselt jälgis ta vene sümbolismi. Õigupoolest ongi veel lahtine, millal tekkis vaimses Eestis arusaamine, et antiiki tuleb tunda seestpoolt, mitte pelgalt ümberjutustuste kaudu. Loogiliselt arutledes sai Jaak Põldmäe alustada oma värsistuudiumi ladinakeelsel põhjal ehk Horatiuse järgi. Kreeka keele prosoodiat võinuks talle õpetada Ülo Torpats, ent on kujuteldamatu näha neid kahekesi mišeerimas ehk käimas Ülikooli ja Munga tänava nurgal püstijalabaaris, mille baarimees olevat olnud Miša-nimeline. Jaak Põldmäe ei armastanud alkoholi ega tubakat (Ülo Torpats oli piibumees). Mille ja kelle järgi tundis kreeka prosoodiat ja meetrikat Horatius ise, seda Tartus Jaak Põldmäe tudengiajal igatahes ei õpetatud, sest Karl Reitav oli siis juba teispool Hadese laiu uksi ja Valmen Hallap töötas Tallinnas. Esimeseks raamatuks, millega Jaak Põldmäed Tšerlaki (linn Irtõši 
jõe ääres) keskkoolis premeeriti, oli Krõlovi valmide rahvaväljaanne. Ent süstemaatiliselt ei ole Krõlovi meetrikat kunagi uuritud ja tema loomaaias neljajalalise jambi tüütusest ei arutletud. Krõlovi haug ei teadnud tsesuuri pikkusest mitte kõige vähematki.

Probleem tuleb sellest, et eestikeelset värssi saab uurida viielt aluselt. Üheks on meie oma rahvaluule. Teiseks luuletamine Martin Opitzi (15971639) järgi. Kolmandaks lähtumine eesti keele kui kvantiteedikeele ehitusest. Neljandana nimetaksin eestikeelse värsskõne kui eestikeelse proosakõne „eitust”. Ja viiendaks teiskeelse luule tõlkimine maakeelde. Karl Reitav, August Annist, Richard Kress (1896-1976), Georg Meri (1900-1983), Betti Alver, Uku Masing, August Sang, Ülo Torpats, Rein Sepp (1921-1995), Harald Rajamets (1924-2007), Ain Kaalep ja Haljand Udam (1936-2005) tegid ära tohutu töö selleks, et luule pääseks maksvusele ise, mitte kaude. Mitte ainult luule kui kujund, vaid ühtlasi kui värss. Andrei Kolmogorov tõlkevärsi meetrikat eraldi ei uurinud, Viktor Žirmunski (1891-1971) ja Mihhail Gasparov seevastu küll. Ent vene nõukogude luule meetrika oli 1960. aastatel üleannetu ja vallatu, mittepuškinlik. Alliteratsioon oli tähtsam kui rütmiline korrapära. Ajalooliselt on tähtis, kuidas tajusid seda olulisust eesti luules Mart Raud, Kersti Merilaas ja Uno Laht, ent lähemalt uuris Jaak Põldmäe üksnes Uno Lahe riimikäsitlust. Samas on küsitav, kui süstemaatiliselt tundis viimane vene luulet, kuid ta edvistas ingliskeelse modernismiga, milles luulet esindas Allen Ginsberg (1926-1997), vasakpoolne rebell nagu Uno Laht isegi. Põldmäe otsis korda, vene nõukogude 1960. aastate lüürikud lõhkusid seda ning Ginsbergile oli kord üldse vastumeelne. Mihhail Gasparov lähtus sootuks muust. Tema jaoks oli klassika mitte kord, vaid kohustus. Kohustus mitte lugeda Homerost ilmtingimata Gasparovi moodi, vaid tunda vanu autoriteete. Nii sündiski 1964. aastal koostöös Sergei Utšenko (1908-1976) ja Jelizaveta Staiermanniga (1914-1991) Suetoniuse (u 69 - u 122) biographica „Valitsejate elust” („De vita Caesarum”) tõlge, millest on avaldatud rohkesti kordustrükke.

Jaak Põldmäe astus Tartu ülikooli sügisel 1961. Värsiõpetuse aluseid luges toona Karl Taev Bernard Söödi järgi, „alusteksti” hoolega varjates. Hilisema professor Veniamin Holševnikovi (1910-2000) „Värsiõpetuse alused” („Основы стиховедения”) ilmus esmatrükis 1962. aasta sügissemestriks, mil Jaak Põldmäe oli eksami sissejuhatuses kirjandusteadusesse juba sooritanud. Tõenäoliselt oli see Juri Lotman, kes juhatas Jaak Põldmäe Andrei Belõi, Boriss Eichenbaumi (1886-1959), Nikolai Trubetskoy (1890-1938), Viktor Žirmunski, Juri Tõnjanovi (1894-1943) ja Roman Jakobsoni (1896-1982) juurde. „Juurde” tähendab siin seda, et Jaak Põldmäe sai Juri Lotmani kaudu lugeda vene värsiteadust algallikatest ega pidanud piirduma kooliõpetajatele mõeldud õppevahenditega, mis ei õpetanud Homerose poeetikat ega raasukesi tema liualt, ammugi mitte barbarite värsiõpetust koloniseeritud Lääne-Euroopas. Osa nimetatutest oli radikaalsed lingvistid, osa jällegi poeetikud. Oli väga lotmanlik mõelda nii, et värsiuurimist on kergem edendada, kui see sünnib poeetika raames ehk ülekantud tähenduses „mitte-formalistlikult”.

Tahan sedakaudu öelda, et Andrei Kolmogorov, Mihhail Gasparov ja Jaak Põldmäe tulid värsiõpetusse täiesti erinevatelt alustelt. Samas osutus Põldmäe kahe esimese taotluste ühendajaks. See polnud tema otsene eesmärk, kuid sai tema sihiks. Sõnastaksin selle sihi küsimusena: kuidas kirjeldada omakeelset värssi esiteks olukorras, kus vastav metakeel pärineb teiskeelsest värsipraktikast, ja teiseks olukorras, milles värsskõne entroopia kasvab, ent 
väldib muutumist proosaks? Andrei Kolmogorovi värsiõpetuslikud artiklid avaldas pealkirjaga „Töid värsiõpetusest” („Труды по стиховедению”) tema noorem kolleeg ja kaasautor Aleksandr Prohhorov aastal 2015. Neid on 16, millest Jaak Põldmäe sai tunda pooli. Neli esimest artiklit ilmusid 1962-1964 ajakirjas Voprossõ jazõkoznanija, mida Jaak Põldmäe luges ilmselt Tartu ülikooli peahoone kolmandal korrusel seminari raamatukogus, sest on vaevalt usutav, et ta sai vastavad numbrid Paul Aristelt, kes siis seda ajakirja koju veel tellis. Kolmogorovi empiiriline materjal pole siinkohal oluline. Tähtis on tema meetod, mis kõige arusaadavamalt on esitatud artiklis „Rõhuosakutest kaasaegses vene luules. Üldiseloomustus” (1963). Selle alguses on fikseeritud selgesti, et värsskõne, mis Kolmogorovi jaoks on alati korrastatum kui proosa, statistikas peab lähtuma sellest, kuidas on värsireas (mis oli Kolmogorovile intuitiivne kategooria) täidetud need positsioonid, milles meetrilise eeskirja järgi peaks asuma pearõhuline silp. Meetrum oligi talle eeskiri, rütmika luuletaja vabadus, mida on lihtsam tõlgendada kui kõikumist standardi piires, mitte aga kui normi ümbertegemist. Ta ei uuri, kus võiks pearõhk venekeelsetes sõnades üldse asuda, vaid eeldab, et pikale silbile kreeka ja ladina keeles vastab vene keeles pearõhuline silp, kuid kui sõna on pikem kui kaks silpi (nt Ilja Ehrenburgil неуверенно, Bella Ahmadulinal незнаемого), siis tekib kaasrõhu ja värsirõhu vahel konflikt. Selles mõttes ei ole дольник ('rõhuosak') Kolmogorovi jaoks mitte värsimõõt, vaid rütmilise liigenduse kaudu kirjeldatav niisugune sõnaline struktuur, mille üheks parameetriks on see, kus ta värsis asub, sest kui ta lõpetab värsirea, võib ta olla ka riimiline (sisealliteratsiooni, mida teadlikult rakendasid Mart Raud, Jaan Kross ja Uno Laht, Kolmogorov ei uurinud). Kuidas see kõik võiks välja näha, selleks oli vaja loendada silbipositsioonide täidetust meetriliselt range ehk dogmaatilise ja meetriliselt peaaegu suvalise ehk quasi-meetrilise värsiloome piiril. Andrei Kolmogorov ei kirjutanud ette ega üle matemaatilise statistika reegleid. Ta kirjeldas piirjuhtumeid ning nende semantilist oreooli (seda mõistet kasutamata). Ja piirjuhtumiks oli meetrilise rutiini murdmine viisil, mida 1960 . aastate algul nimetati vabavärsiks lahutatuna neljajalalisest jambist, mille kui dominandi vastu protesteeris aastal 1830 juba Puškin („Majake Kolomnas”: „Meil neljajalgne jamb on esinend / liig sageli - tast isu täis on ammu.").

Samas ei olnud kõik värsid fonoloogiliselt vabad. Uno Lahel oli küll „e2 - e4” (1967), kuid Mart Raual on ka „Ma olin, või õigem: / Mea olli” (1964). Keel võib muutuda ka värsi sees. See oli nii juba Puškinilgi (Betti Alveri tõlkes): „Kord vale! kirjade finaalis”. Luule vajas avatust, meetrum nõudis korda. Kolmogorov koos kaasautori Aleksandr Prohhoroviga uuris seda, kuidas kaasrõhulise silbi nihkumine pearõhulisse positsiooni lööb korra segamini. Eesti luules on see problemaatiline Juhan Liivil, Ernst Ennol ja Gustav Suitsul. Põldmäel oli valida Karl Eduard Söödi ning Jaan Kärneri vahel. Juri Lotman ei saanud talle öelda, et võtke Kärner. Harald Peep jällegi ei hakanud ütlema, et võtke Sööt. Müstiline küll, ent Jaan Kärner oli kõige lollikindlam.

Jaak Põldmäe lugemus 1960. aastate lõpuks on avatud tema artiklis „Statistiline meetod nõukogude värsiteoorias” (1969). Seal pidas ta programmiliseks Andrei Kolmogorovi ja Aleksandr Kondratovi artiklit „Majakovski poeemide rütmika" (1962), mis tegelikult ei kehtesta mingit kava värsiteaduse edendamiseks, vaid juhib tähelepanu erinemisele normist, millest kroonutruu kinnipidamine võib luule tappa. Kolmogorov ise märkis, et temapoolne käsitlus lähtus Vladimir Nikonovi (1904-1988) artiklist „Majakovski rütmika” (1958). 
Põhimõtteliselt ongi tähtis, mis järjekorras luges Jaak Põldmäe kellegi töid värsiõpetusest ja kui täielikult ta seda teha sai. Aastatel 1957-1958 algaski tema kirjandusteaduslik lugemus, kuna siis hakkasid ilmuma Keel ja Kirjandus, „Paar sammukest”, Voprossõ literaturõ, Russkaja literatura ning oli võimalik tellida ajakirju Sinn und Form (1949) ja Weimarer Beiträge (1955). NSVL TA Vene Kirjanduse Instituudi (Puškini Maja) väljaandeid jälgis tähelepanelikult Mart Lepik. Pole viljakas oletada, kui põhjalikult võisid Põldmäed ning Mart Lepik ja Betti Alver uusimast kirjandusteadusest kõnelda, aga ei ole usutav, et nad poleks seda teinud. Siiski on mõeldav, et nad kõik, niisiis ka koolipoiss Jaak Põldmäe, tundsid Boriss Tomaševski (1890-1957) asjaomaseid töid, kuivõrd need parajasti ilmusid: 1956 „Puškin” I, 1959 „Stilistika ja värsiõpetus” ning „Värss ja keel”, lisaks artiklid kogumikes. Tomaševski ise oli olnud autoriteet juba Gustav Suitsu jaoks ja Jaan Toomlast (1929-2007) pidi saama Tomaševski aspirant tekstoloogias (vahetult ajas Jaan Toomla asju väga autoriteetse bibliograafi dr. Ksenia Muratovaga (1904-1998)). Neid asjaolusid arvestades kaldun arvama, et Tomaševski tööde juurde juhatasid koolipoiss Jaak Põldmäe algul tema isa ja Mart Lepik ning Juri Lotman lisandus alles hiljem.

Värsiõpetuslikku korda tolles varasemas lugemuses olla ei saanud, sest Rudolf Põldmäe oli kirjandusloolane ja folklorist, kes suhtus kriitiliselt nii Walter Andersoni (1885-1962) monograafiasse „Silpide statistika eesti vanades rahvalauludes” („Studien zur Wortsilbenstatistik der älteren estnischen Volkslieder”, 1935) kui ka Eduard Laugaste (1909-1994) doktoriväitekirja „Sõnaalguline ja sisealliteratsioon eesti rahvalauludes. Eesti rahvalaulu struktuur ja kujundid I" (1969, kaitstud 1970). Aino Undla-Põldmäe oli aga Koidula monograaf, kes ei läinud rajalt väljapoole. 1960. aastate aegruumis olnuks täiesti võõrastav kirjutada eestlasena olevikulisest vene nõukogude värsist vene luule ajaloo raamides. Kirjutada sellest, mis on värss kui niisugune, eeldanuks jällegi 4-5 keele prosoodilise struktuuri võrdlemist ning ühtlasi matemaatilise statistika aluste valdamist. Keeled võinuksid olla vene, saksa, inglise, prantsuse ja soome. Saksa uuemat luulet oli kodus mõnevõrra Nigol Andresenil ja Ain Kaalepil, prantsuse luulet jälgis Ain Kaalep, ingliskeelset luulet Uno Laht, luulet Soomes Paul Rummo ja Paul-Eerik Rummo. Kogude läbitöötamiseks oleks Jaak Põldmäe pidanud käima neist kõigi juures küsimas seda ja teist. Olema manuline. Tema valis iseenesest õige tee. Ta ei uurinud näiteks seda, milline oli Boriss Tomaševski statistiline mõtlemisviis. Selleks oleks tulnud käia mitme aasta vältel Peterburis. Tema hakkas uurima seda, kui mitmel viisil on eestikeelne värss üldse korrastatav ja - mis on eriti tähtis - kui ebamäärane on vabavärsi ja proosa vaheline piir. Proosa piiri märgib maha trükirea lõpp, mille nimel tegutseb metteur en pages. Värsi lõppu tähistab algamine järgmisest värsist. Lõppriim võib olla fakultatiivne, värsi algus on kohustuslik.

Aastail 1968-1970 avaldas Jaak Põldmäe neli suurt põhimõttelist artiklit, sealhulgas metoodiliselt originaalse „Jaan Kärneri meetrika” (1970). Nüüdses mõistes filosoofiadoktori väitekirja sisu oli valmis ning ka publitseeritud. Tartus oleksid võinud teda juhendada Harald Peep kui kateedrijuhataja ja Villem Alttoa kui filoloogiadoktori kraadiga professor (ning samuti kateedrijuhataja). Nagu mainitud, viibis esimene aastail 1968-1970 doktorantuuris ja oli muust täiesti vaba, teine oli XIX sajandi lõpu ja XX sajandi alguse eesti kirjanduse ajaloo uurija. Põldmäe ametlikuks juhendajaks kinnitati NSVL TA 
Slavistika ja Balkanistika Instituudi struktuurse tüpoloogia sektori juhataja (1961-1989) Vjatšeslav Vs. Ivanov (1929-2017), ääretult viljakas filoloog ja entsüklopeediline lingvist peamise rõhuasetusega indoeuroopa keelte ajalool. Tema juhatas Juri Lotmani koolkonda Moskva poolt, ent olgu täpsustatud: mõlemad tegid seda väga demokraatlikult, nii et Ivanovit eraldi esile tõsta pole päris õige. Ta „lihtsalt” töötas ametikohal, mis andis talle suure vabaduse koos küllaldaste õigustega, ka juhendamisõiguse. Värsiõpetusest oli ta selleks ajaks avaldanud pool tosinat teaduslikku artiklit ja pidanud aastal 1961 Nižni Novgorodis ettekande värsisüsteemide aksiomaatikast.

Aastal 1971 oli Jaak Põldmäe dissertatsioon käsikirjas lõpetatud. Pealkirja järgi koosneb see kahest poolest, millest esimene on pühendatud eesti luule värsisüsteemidele, teine eesti luule silbilis-rõhulisele värsisüsteemile XX sajandil. Siiski pole esimene osa kitsalt teoreetiline ja teine ajaloolis-näiteline. Põldmäe muutis värsiteooriat mõlemas pooles, sest ta otsis niisugust poeetilise meetrika ühikut, mis sobiks silbiehituse kirjeldamiseks värsskõnes kõrgemalt vaatekohalt kui omapärasused keelkonniti. Koolipoisilikult sõnastades on silpi iseloomustatud viie parameetriga: 1) silbi häälikuline pikkus (silp võib olla ka ühehäälikuline); 2) hääliku(te) rõhulisus; 3) hääliku(te) välde; 4) hääliku(te) kvalitatiivne koosseis ehk vokaalsus/konsonantsus; 5) silbi asukoht värsis. Ükski nendest parameetritest pole konstantne, nad on kõik dünaamiliselt funktsionaalsed. Kõige nähtavamalt tuleb see esile värsskõne kirjeldamisel ekvimeetriliselt vaatekohalt, kuid ka riimiteoorias ja stroofikas. Võib-olla oli see Vjatšeslav Vs. Ivanov, kes arvas, et puhtteoreetiline uurimus värsiasjandusest ehk algebraline meetrika ei tarvitse kinnitamisel läbi minna, sest on liiga radikaalne; järelikult on kindlam, kui dissertant lähtub kõige traditsioonilisemast värsisüsteemist, mille tüpoloogia on üldiselt niigi teada, ja illustreerib seda sellise luuletaja loomingu kaudu, kellele pole midagi ideoloogilist ette heita. 1940.-1980. aastatel jagunes Kõrgema Atestatsioonikomisjoni distsiplinaarne nomenklatuur kirjanduses neljaks: vene kirjanduse ajalugu, NSVL-i rahvaste kirjandus, väliskirjandus ja kirjandusteooria. Kõigis neljas valdkonnas eeldati, et väitekiri peab olema ajaloo- või ka arengulooline - või ta jooksutati kinni ehk jäeti esitatud kujul kinnitamata. 1968. aastal lükkas keskvõim tagasi Pjotr Rudnevi (1925-1996) kandidaaditöö Aleksandr Bloki meetrikast ja kuigi ta Tartus tegi selle pisut teistsuguseks, otsustas töö kinnitamise peamiselt ikkagi tõsiasi, et selle esimeseks oponendiks sai Peterburi akadeemik Viktor Žirmunski: oli vaja, et Rudnev oleks kaitsnud, ja oli vaja Moskvas, et see väitekiri oleks ka kinnitatud, milleks kutsutigi Tartu ülikooli peahoonesse Žirmunski. 1974. aastal jäeti Tartus esimesel katsel kinnitamata Smolenskis töötava Vadim Bajevski (1929-2013) doktoritöö vene lüüriliste poeemide poeetikast. Esialgu tundus, et Jaak Põldmäe disponeeritud uurimusega ei tohiks probleeme olla, ent need tekkisid otsekohe, kui väitekirja kaitsmisel 1972 hakkas tunduma, et mahult ja sügavuselt väärib töö tunnustamist filoloogiadoktori astmes. Üheks ettekäändeks lükata nõukogu asjaomane otsus tagasi sai Moskva-poolne hinnang, et kaitsmisnõukogu polnud vajalikult komplekteeritud, teiseks oli Jaak Põldmäe käsitlus aga järelekspertide ja nn mustade retsensentide meelest ikkagi „formalistlik” ja traditsioonidest väljuv. Ükski akadeemiline argument ei toiminud. Aastal 1976 kinnitati tema uurimus ikkagi vaid kandidaadikraadi ulatuses.

Kui kaugele Jaak Põldmäe oma „värsiaatomi” otsingutes jõudis? Iktus on tegelikult prosoodiline kategooria, silbi need parameetrid, mis kirjeldavad 
tema omadusi siis, kui ta asub värsijala tõusul. Ses mõttes on näiteks jambi algus „deiktilisem” kui lõpp. Paraku ei sobi niisugune lähenemisviis vabavärsi kirjeldamiseks, sest vabavärss sünnib jalutuna (ma pean silmas radikaalset, mitte liberaalset vabavärssi). Ühelt poolt näitas Jaak Põldmäe, et vabavärss võib olla toonilise värsisüsteemi piirjuht, teiselt poolt, et ta võib olla polümeetriline struktuur, kolmandast küljest ei oleks absurdne kirjeldada vabavärsina ka näiteks värssteksti proosatõlget, milles on siiski vaja säilitada originaali semantiline rütm. Lisaks meetrilisele paradigmaatikale oleks sel juhul läinud vaja süntagmaatilist, ent Jaak Põldmäe ei tahtnud piirduda ääremärkustega kõigele. Vastasel korral oleks ta pidanud Leonard Bloomfieldi (1887-1949) jälgedes süvenema tagmeemikasse. See oleks nõudnud algusest peale puhtlingvistilist stuudiumit. Alternatiiv sellele seisnenuks kujundite kirjeldamises täiesti emotsionaalselt aluselt, nii-öelda Timofejevi moodi. Hulgateoreetiline lähenemine värsskõne fonoloogiale poleks aga leidnud teemana kinnitamist ega tõenäoliselt isegi mitte artiklitena avaldamist. Jaak Põldmäe valis aineks eesti värsi, ühes sellega ka eesti regivärsi ja sekundaarse regivärsi.

Tema üldine seisukoht näikse olevat see, et igasugune värss on pigem heterogeenne (või koguni polümeetriline) kui homogeenne, millest järgneb, et meetriline kaanon toimib tegelikult nagu diktatuur. Selles mõttes ei viinud Eduard Laugaste eesti regivärsi meetrika uurimist edasi mitte millegi poolest ja tõesti, ta uuriski enda arvates häälikute, tegelikult aga häälikuid tähistavate trükitähtede kvalitatiivset struktuuri regivärsi sisse paigutatud sõnade algul („Kui tuleb kurja, kus sa küüdad?” Kolga-Jaani) ning sees („käetäied kärme'emad" Virumaa). Seda heterogeensust võib tõlgendada kui rütmikat, aga ka kui meetrika metakeelelist ebatäiuslikkust. Jaak Põldmäe käsitlustest võib välja lugeda, et ta arvas pigem viimast. Sellest siis ka tahtmine leida värsiõpetuse metakeelele säärane mõõduüksus, kus näiteks silbi pikkus ja rõhulisus oleksid võrdväärsed sõltumatult sellest, kas neid saab teineteisega asendada või mitte (äraseletatult: kas pikk silp on ekvimeetriline pearõhulise silbiga üleüldse või ainult teatavatel tingimustel). Omas ajas ta ju nägi, kuidas eesti värss pole enam rangelt opitzlik. Kui Mats Traadi „Seestumine” (1967) seda on, siis tema „Meie Ema palve” (1965) ei ole.

Aspirantuuriaastail tutvus Jaak Põldmäe aktiivsete värsiteadlastega vahetult. Tartus, Käärikul, Kolomnas. 1968. aastal toimus Kolomnas värsija luuleuurijate konverents, mille korraldas Pjotr Rudnev, ent mida ajendas seegi, et Boriss Pilnjak (1894-1938) oli elanud seal ühtekokku 8-9 aastat. Mõnesuguse pildi saab Jaak Põldmäe tutvuskonnast tema koduse raamatukogu põhjal, kus leidub kümmekond pühendusega raamatut. Nendest rohkem ütlevad pehmeköitelised teosed üksikute rahvaste värsiõpetuse kohta, näiteks Nikolai Kuturovi venekeelne „Mari värsiõpetus” („Марийское стихосложение”, 1976), mille Jaak Põldmäe sai autorilt jõuludeks 1976. Sellest on ta töötanud läbi mari rahvalaulude rütmika. Kuid need raamatud ei mõjutanud Jaak Põldmäe väitekirja. Kõige põhjalikumalt uuris ta kogumikku „Värsiteooria” („Теория стиха”, 1968) ning kogumikust „Teaduste koostöö ja loomingu saladused” („Содружество наук и тайны творчества”, 1968) Veniamin Holševnikovi ning Andrei Kolmogorovi ja Aleksandr Prohhorovi värsiõpetuslikke artikleid. Kohe alguses sai talle selgeks, et eesti värssi ei saa uurida samal viisil nagu vene värssi, kuid oli vaja saada aru, kuhu on vene värsi uurimine jõudnud ja mida see ütleb kui mitte üldise, siis vähemasti võrdleva värsiõpetuse kohta. Ütles see aga järgmist: eesti luules on värsisüsteemide arv suurem kui kaas- 
aegses vene luules ja nimelt kvantiteeriva värsi ning selle kombinatsioonide tõttu. Aastal 1969 visandas sellekohase üldise aksiomaatika professor Boriss Buchstab (1904-1985). Mordva rahvalaulude meetrilise aksiomaatika ehitasid aastal 1941 üles Roman Jakobson ja Ameerikas töötanud Janos Lotz (1913-1973), kelle tookordne käsitlus on jäänud Eestis paraku tundmatuks. Laiendatud kujul publitseeris Janos Lotz selle aastal 1968, oma meetrika tüpoloogia - seda oli Põldmäe lugenud - aga juba 1960. Mõistatuslikel põhjustel ei näi Jaak Põldmäe olevat tuttav Mihhail Stockmari monograafiaga „Uurimusi vene rahvalaulude värsiõpetusest” (Исследования в области русского народного стихосложения", 1952). Stockmari uurimus nimelt algabki värsisüsteemide teooriast, täpsemalt antiikmeetrika kategooriate ülekantavusest vene värsi kirjeldamiseks. Tõenäoliselt polnud Tartus kedagi, kes oleks Jaak Põldmäe juhatanud Stockmari juurde.

Paratamatult luges Jaak Põldmäe seda, mida ta kätte sai. Siiski luges ta uurimusi valikuliselt. 1960. aastate vene värsiteaduses oli „päevaautoriks” Vladimir Majakovski, kelle luules said kokku värsiõpetuse kõik paradigmad: prosoodia, meloodika, meetrika ja rütmika konflikt, silpide ning sõnade riimiline struktuur, värsskõne süntaks, stroofika, vabavärss, polümeetrilised kompositsioonid ja lüüriline proosa (Majakovskil peaaegu puuduvad neutraalsed pealkirjad, vt näiteks „Vaat sedamoodi ma muutusin koeraks”, 1915). Ent Jaak Põldmäe ei olnud monograaf, ta ei uurinud teiste rahvaste luulet üksikute autorite kaupa. Teda huvitas paradigmade seotus alates sellest nurgakivist, mis on värsiehituses määratletud fonoloogiliste eristustega (Jaak Põldmäe eristas nii binaarset kui ka ternaarset opositsiooni). Leksikoloogilised hajamärkmed Viktor Vinogradovi moodi ehk lugemisnopmed Paul Ariste kombel poleks värsiõpetuses olnud nii metoodilised nagu värsimassiivi maatriksanalüüs, mis oli Mihhail Gasparovi ideaaliks. Andrei Kolmogorov ja Viktor Žirmunski uurisid värsitehnikas kas iseloomulikke või kriitilisi juhtumeid, mitte ei võtnud läbi kõiki värsse, nagu seda Gasparovist veelgi suuremas mahus tegi Kirill Taranovski (1911-1993). Vastavalt oli Kolmogorovi ja Žirmunski näitematerjal küllalt väljavõtteline kas autoriti, mõõduti või isegi tekstiti. Jaak Põldmäe uuris värssi teistest erinevalt. Tema jaoks oli üheks meetriliseks käänupunktiks mitterange silbilis-rõhulise värsisüsteemi tüpoloogiline üleminek tooniliseks olukorras, kus värss asümptootiliselt läheneb proosale, ja teiseks rütmitu proosa ümberpööre niisuguse silbilis-rõhulise värsi suunas, milles meetrika ja rütmika langevad peaaegu kokku. Silbilis-rõhulises värsisüsteemis on asjale sedapidi vaadates olulised statistilised, vabavärsis tüpoloogilised näitajad.

Kuna sellekohaseid uurimusi - mõeldud on originaalseid käsitlusi, mitte ülevaatlikke sissevaateid - ilmus 1960. aastatel vähe, jäi üle arutleda probleeme suulises diskussioonis näost näkku. Umbes nii Jaak Põldmäe sõbruneski Mihhail Gasparoviga hiljemalt 1968. aastal. Kummagi empiiriline materjal oli erinev, sest Jaak Põldmäe tegeles ka sekundaarse regivärsiga, mis näiteks Eha Lättemäel ei ole imitatsiooniline. Lugemuski polnud sama, sest Jaak Põldmäe oli töötanud läbi Soome teeneka leksikograafi Matti Sadeniemi (1910-1989) doktoritöö soome värsiõpetuse põhimõtteist („Metriikkamme perusteet ja sovellutusta moderneihin ja antiikin mittoihin”, 1949) ja selle jätku „Kalevala-värsi meetrika” („Die Metrik des Kalevala-Verses”, 1951). Vana rahvalaulu värsiehitusest moskvalane ning tartlane ilmselt ei kõnelnud, sest puu- 
dus ühisosa. Küll on teada, et jutuks tuli riim - aga mitte selle puudumine lõppriimi kujul siis, kui värss on kas antiikne või vaba. Räägiti riimilise sõna fonoloogiast ja selle kirjeldamise baasühikust. Mitte täis- ega irdriimist värsi lõpul, vaid $n$-riimi tõlgendamisest kooskõlas silpide rõhulisusega. On mõeldav, et Mihhail Gasparovi ja Jaak Põldmäe ühiseks vestlusaineks olid Viktor Žirmunski 1960. aastatel ilmunud värsiõpetuslikud artiklid, milles autor ei varjanud oma skepsist värsile puhtstatistilise lähenemise suhtes. Võimalik, et Mihhail Gasparov juhtis noorema kolleegi tähelepanu asjaolule, et riimil on häälikulise struktuuriga kõrvuti ka tooniline struktuur, kusjuures see ei tarvitse olla sümmeetriline (August Sangal „mul : hommikul”; „lamaks : avaramaks”; „hommikuni : uni”). Vastavad näited pidid pärinema vene keelest, sest seda oskasid mõlemad. Ent kui Jaak Põldmäe hakkas pidama loenguid, siis poeetilised illustratsioonid otsis ta kannatlikult eesti kirjandusest, kasutades kreeka, rooma ja vene ainesest üksnes metakeelt.

Värsiõpetus kui poeetika osa kuulus Jaak Põldmäe loetud kursustesse sissejuhatusest kirjandusteadusesse ja kirjandusteooriast valitud peatükkide ulatuses. Need haarasid põhimõisteid, mitte põhimõtete ning nende rakendamise ajalugu. Niisiis luges ta oma aineid eest taha, mitte vastupidi. Niisuguse lähenemisviisi raskus seisnes selles, et, välja arvatud August Sang ja Artur Alliksaar, oluliste autorite luuletajapilt oli avatud, sest kõik võisid jätkata. Noort õppejõudu, kes oli veel paberites kinni, sundis värsitehnika muutumine kogu aeg otsima. Kuid improviseerida ta ei armastanud. Iga loeng oli eelnevalt läbi mõeldud. See, mida me kuulsime, oli iseseisva töö tulemus, mitte kriibuskraabus ümberjutustus. See kutsus kaasa isegi neid, kes ei saanudki aru, kui pikk on heksameeter.

Tähtvere mõisas 12. IX 2017

Tänan südamest kauaaegset kirjastustoimetajat (ja Jaak Põldmäe kursusekaaslast) Ants Haljamaad, kes leidis oma vanema kolleegi Richard Kressi sünni- ja surma-aasta.

\section{Käesolevate lehekülgede mõistmiseks on kasulik lugeda järgmisi kirjutisi:}

Põld m ä e, Jaak 1968. Eesti silbilis-rõhulisest värsisüsteemist aastail 1917-1929.

- Keel ja Kirjandus, nr 8, lk 449-459; nr 9, lk 533-542.

Põld mä e, Jaak 1969. Eesti rõhulisest värsisüsteemist. - Looming, nr 6, lk 928940.

Põld m äe, Jaak 1969. Statistiline meetod nõukogude värsiteoorias. - Keel ja Kirjandus, nr 10, lk 591-599.

Põld m äe, Jaak 1970. Jaan Kärneri meetrika. - Töid eesti filoloogia alalt (TEFA) III. Tartu: Tartu Riiklik Ülikool, lk 201-272.

Põld m ä e, Jaak 1981. Typologie du vers libre. - Linguistique et poétique. Moscou, lk 290-304.

Hennoste, Tiit 2012. 20. sajandi eesti kirjandusteadus Euroopa kirjandusteaduse taustal. - Vikerkaar, nr 4-5, lk 166-176.

Oles k, Peeter 2008. Filoloogia tõeline tähendus. Tartu: Ilmamaa, lk 224-248. 
Гаспаров, Михаил 2012. Записи и выписки. Москва: Новое литературное обозрение, lk 296-301.

Егоров, Борис 1973. Аксиоматическое описание русских систем стихосложения. - Искусство слова. Сборник статей к 80-летию члена-корреспондента АН СССР Дмитрия Дмитриевича Благого. Москва: Наука, lk 388-392.

Жир м унский, Виктор 1975. Теория стиха. Ленинград: Советский писатель, lk 539-568.

Ко л м о го р о в, Андрей 2015. Труды по стиховедению. Москва: МЦНМО, lk 37-46, 109-155, 181-214.

\section{Jaak Põldmäe's contribution from a comparative perspective}

Keywords: verse prosody, Estonian verse typology, Russian versification studies, Jaak Põldmäe, Andrei Kolmogorov, Mikhail Gasparov

The article addresses the contribution of Jaak Põldmäe (1942-1979), former Assistant Professor of the University of Tartu, to the knowledge of Estonian versification. Before Jaak Põldmäe's innovative studies, Estonian verse had been analysed within individual systems, without even wondering about the possible number and internal articulation of such systems. Jaak Põldmäe managed to answer both the questions, also demonstrating that a purely quantitative verse is not marginal at all, and that free verse is far from anarchic inside. To reach these results, he carefully studied the relevant articles by mathematician Andrei Kolmogorov and student of antiquity Mikhail Gasparov, in addition to the whole metric experience contemptuously called formalist by the devout Soviet Russian scholars.

Peeter Olesk (b. 1953), Advisor of the Rector of the Estonian University of Life Sciences, prouadoktor@gmail.com 